\title{
Metformin - a new old drug
}

\author{
Marta Patrycja Wróbel', Bogdan Marek², Dariusz Kajdaniuk², Dominika Rokicka', \\ Aleksandra Szymborska-Kajanek ${ }^{1}$, Krzysztof Strojek ${ }^{1}$
}

${ }^{1}$ Department of Internal Medicine, Diabetology and Cardiometabolic Disorders, School of Medicine with the Division of Dentistry in Zabrze,Medical University of Silesia, Zabrze, Poland

${ }^{2}$ Department of Pathophysiology and Endocrinology, School of Medicine with the Division of Dentistry in Zabrze, Medical University of Silesia, Zabrze, Poland

\begin{abstract}
For many years metformin has been the gold standard in the treatment of type 2 diabetes. According to recommendations of the most important diabetes associations, this is the first-choice drug for use as monotherapy in patients with newly diagnosed type 2 diabetes. Metformin is also recommended in combined treatment when monotherapy is no longer effective. It is then combined with a sulfonylurea, an incretin, flozin, or insulin, irrespective of the number of insulin injections per day. Besides its properties used in the treatment of diabetes, metformin has been treated for some time as a drug of a so-called pleiotropic activity, as each year brings new reports about its favourable effect in different conditions. At present, the scope of reimbursed indications of this drug has been expanded to include prediabetes, insulin resistance syndromes, and polycystic ovary syndrome. Metformin does not stimulate insulin secretion by the beta cells of the pancreas, and thus it is a drug that does not cause hypoglycaemia. The blood glucose-lowering effect of the drug is a consequence of hepatic glucose production inhibition, and of peripheral tissue (muscle tissue, fatty tissue) sensitisation to the effect of insulin of both endogenous and exogenous origin. The exact mechanism of metformin action at the cellular level remained unknown for a long time. Studies performed in recent years have provided a great deal of information that enables better understanding of the mechanism of action of the drug as well as the clinical effects resulting from its use. Metformin, besides improvement of glycaemia, is neutral to body weight, is cardioprotective, improves lipid profile, and has a probable anti-cancer effect. Metformin accumulation in the intestinal mucosa may interfere with FDG (18F-deoxyglucose) PET-CT image assessment. The aim of this article is a detailed discussion of metformin properties, its mechanisms of action, and clinical effects. Endokrynol Pol 2017; 68 (4): 482-495
\end{abstract}

Key words: metformin; metformin properties; type 2 diabetes

\section{Introduction}

Since the late 1990s metformin is the gold standard in the treatment of type 2 diabetes. According to recommendations of the most important diabetes associations, this is the first-choice drug for use as monotherapy in patients with newly diagnosed type 2 diabetes. Metformin is also recommended in combined treatment when monotherapy is no longer effective. It is then combined with a sulfonylurea, an incretin, flozin, or insulin, irrespective of the number of insulin injections per day $[1,2]$. Metformin is the only commonly economically available product that, besides the glucose lowering effect, has a favourable effect on the body weight. This is important because the diabetic population are usually overweight. Besides its properties used in the treatment of diabetes, metformin has been treated for some time as a drug of a socalled pleiotropic activity, as each year brings new reports about its favourable effect in different conditions $[3,4]$. At present, the scope of reimbursed indications of this drug has been expanded to include prediabetes, insulin resistance syndromes, and polycystic ovary syndrome.

\section{Metformin's mechanism of action}

Metformin does not stimulate insulin secretion by the beta cells of the pancreas, and thus it is a drug that does not cause hypoglycaemia. The blood glucose-lowering effect of the drug is a consequence of hepatic glucose production inhibition and of peripheral tissue (muscle tissue, fatty tissue) sensitisation to the effect of insulin, of both endogenous and exogenous origin. The exact mechanism of metformin action at the cellular level remained unknown for a long time. Studies performed in recent years provided much information that enables better understanding of the mechanism of action of the drug as well as the clinical effects resulting from its use. The current knowledge in this field is presented below. - Metformin interferes with cellular respiration by inhibition of mitochondrial respiratory chain complex I (mitochondrial stress), which leads to a decrease of intracellular ATP, which imitates a cell starvation condition. As a result, the AMP pool increases and this stimulates the AMP-activated protein kinase (AMPK) that is a so-called cellular energy sensor. 
AMPK is activated even at a minor ATP deficit. This leads to "downregulation" of all metabolic pathways that consume energy - proliferation, and protein and lipid synthesis [5]. ATP production increases, in turn, through an increased uptake of glucose from the blood, increased glycolysis (and thus increased glucose utilisation and a decrease of its blood level), and fatty acid beta-oxidation. AMP molecules activate AMPK directly through binding to the gamma-subunit of the enzyme or indirectly through inhibition of its dephosphorylation. Stimulation of the AMPK increases also translocation of glucose transporters - GLUT - towards the cell membrane, and intensifies glucose transport into the cell (increased glucose utilisation) (Fig. 1, Table I) [6];

- Based on the results of recent studies, metformin appears to act also independently from AMPK activation. By inhibiting mitochondrial respiratory chain complex I, metformin leads to production of reactive oxygen species (ROS) and generates a so-called integrated stress response (ISR) via activation of transcription factor 4 (ATF-4), which activates fibroblast growth factor-21 (FGF-21) [7, 8]. This pathway is completely independent of AMPK, which was confirmed in studies conducted on a culture of fibroblasts from rodents deprived of the AMPK gene. Until recently, FGF-21 produced by hepatic cells was considered to be a factor involved only in glucose and lipid metabolism, but it appears to have also a role in the mechanism of action of metformin. FGF-21 level was observed to change in people treated with metformin [9];

- Metformin is widely known to inhibit hepatic gluconeogenesis [10]. However, the mechanism of action of this drug in this respect has been understood only recently. There are data suggesting that metformin inhibits mitochondrial glycerophosphate dehydrogenase (mGDP) - a key enzyme linking metabolic pathways of carbohydrates and lipids (without affecting the cytosolic glycerophosphate dehydrogenase; cGDP) [11]. In normal conditions, this pathway allows for entrance of the reduced form of NAD (NADH+), being the product of cytoplasmic glycolysis, into the mitochondria, where ATP production and cytoplasmic NAD+ regeneration occurs. Inhibition of mGDP hampers conversion of glycerol-3-phosphate to dihydroxyacetone phosphate (DHAP), thus inhibiting gluconeogenesis from glycerol. As a result of decreased NAD+ level (oxidised form of NAD) lactate cumulates as its transformation to pyruvate (a reaction catalysed by lactate dehydrogenase) is impaired in such conditions, and additionally hepatic gluconeogenesis is inhibited [10] (Fig. 1). Lactate accumulation at the cellular level is a typical phenomenon during metformin therapy; however, its amount is harmless if the drug is used after consideration of contraindications (Table III);

- Another explanation of metformin's inhibitory effect on hepatic gluconeogenesis was published a few years ago in "Nature". Glucagon is also responsible for hepatic gluconeogenesis. Excessive glucagon secretion by pancreatic alpha cells in type 2 diabetic patients is one of the elements of complex pathogenesis of this type of disease. Glucagon, by binding to a receptor on the hepatocyte activates the adenylate cyclase and thus promotes cyclic AMP (cAMP) formation, which stimulates protein kinase A (PKA), leading to hepatic glucose production. The authors of this work state that metformin weakens the effect of glucagon after binding to the receptor, through reduction of cAMP production in liver cells. This is because metformin, which, by inhibiting mitochondrial respiratory chain complex I, leads to AMP accumulation, which in turn inhibits adenylate cyclase, and thus cAMP production. A decreased amount of cAMP inhibits the activity of PKA and thus diminishes hepatic gluconeogenesis [12] (Fig. 1).

- Additionally, metformin induces secretion of glucagon-like peptide-1 (GLP-1) by L-cells of the small intestine and sensitises beta cells of the pancreas to its action, among others by affecting the expression of the GLP-1 receptor on these cells [13, 14]. GLP-1 is an incretin hormone, whose deficiency or impaired activity plays an important role in the pathogenesis of type 2 diabetes. In physiological conditions, GLP-1 is responsible for increased insulin secretion by the beta cells of the pancreas in response to food ingestion. GLP-1, by binding to the relevant receptor on the beta cell (other than sulfonylurea receptor), stimulates an insulin secretion adjusted to the blood glucose level, thus not generating hypoglycaemia. Due to treatment safety (a minimal risk of hypoglycaemia), among others, the drugs improving the incretin effect that is impaired in diabetes (so-called incretins) are more and more widely used in the treatment of type 2 diabetes. They include GLP-1 analogues (agonists of the GLP-1 receptor on the beta cells of the pancreas) and inhibitors of dipeptidyl-peptidase 4 - the enzyme responsible for GLP-1 breakdown. A combination of an incretin and metformin is therefore fully justified, taking into consideration the confirmed synergism of action of these drugs;

- Metformin is also active within the intestines, where it increases glucose uptake and utilisation. It was found that the metformin level in the intestinal mucosa reaches the highest values, as compared 


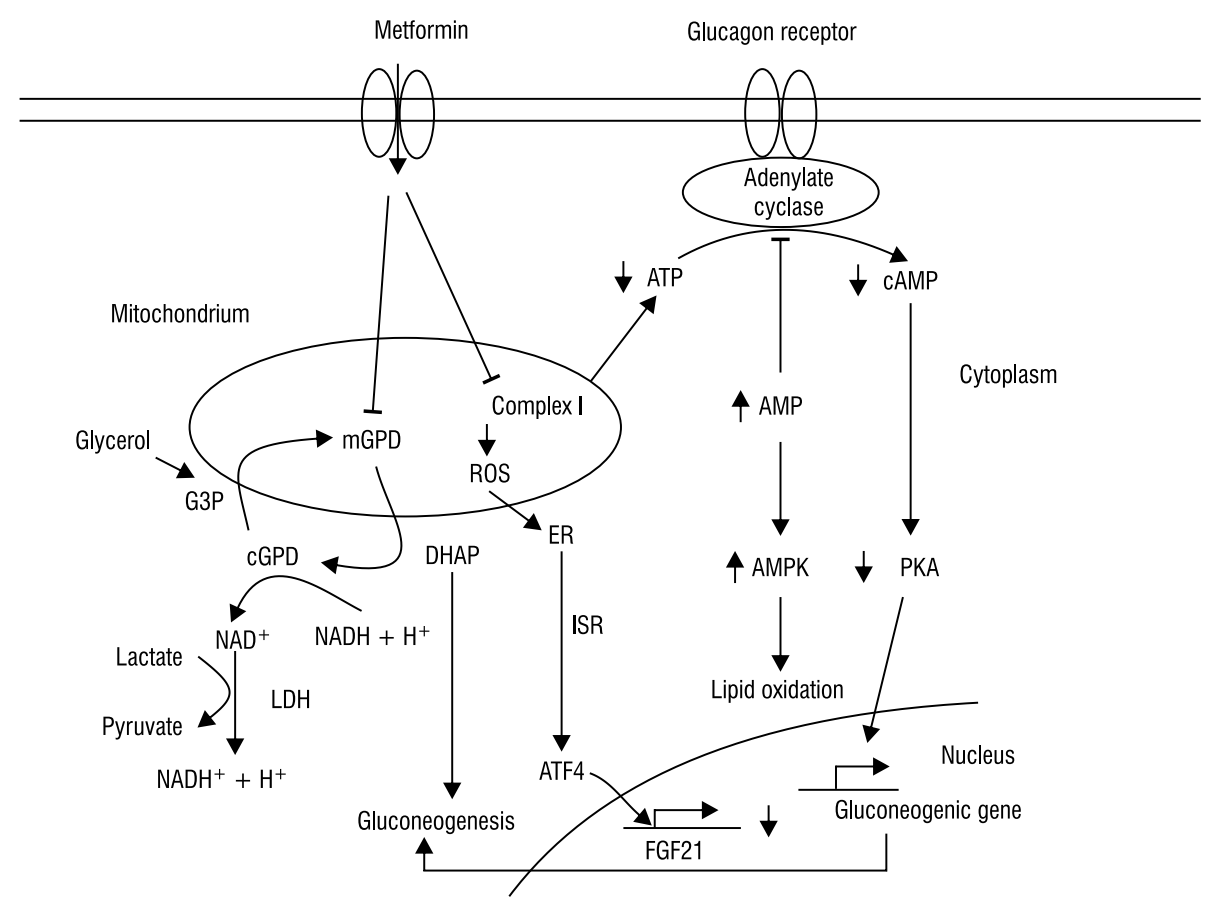

Figure 1. Mechanisms of metformin action

Legend: AMPK - monophosphate - activated protein kinase, ATF-4 — activating transcription factor 4, COMPLEX 1 mitochondrial complex I, DHAP — dihydroxyacetone phosphate, ER —endoplasmic reticulum, FGF21 — fibroblast growth factor 21, G3P - glycerol-3-phosphate, ISR — integrated stress response, cGPD — cytosolic glycerophosphate dehydrogenase, mGDP mitochondrial glycerophosphate dehydrogenase, PKA - protein kinase A, ROS — reactive oxygen species

Table I. The effects of AMP-kinase activation by metformin

\section{Due to activation of AMPK}

Hepatic production of glucose (glycogenolysis and gluconeogenesis) is reduced

Peripheral glucose uptake and utilisation by muscles increases

Glut translocation towards cell membrane is activated, which increases the uptake of glucose from circulation

Lipogenesis is reduced

Beta-oxidation (utilisation of free fatty acids) is activated

\section{Table III. Contraindications to metformin use}

\section{Metformin is contraindicated in all hypoxic conditions}

Kidney failure (usually, the drug should be discontinued or its dose reduced at GFR $<60 \mathrm{ml} / \mathrm{min}$ - as specified in the Summary of Product Characteristics [SPC]). According to the Summary of Product Characteristics for Glucophage, this drug may be used in patients with moderate kidney failure (GFR $45-59 \mathrm{~mL} / \mathrm{min} / 1.73 \mathrm{~m}^{2}$ ) if no other factors increasing the risk of lactic acidosis are present. A lower drug dose is administered $-1000 \mathrm{mg} /$ day, at the maximum, divided into two doses

Circulatory failure (advanced — NYHA III, IV), myocardial infarction, shock

\begin{tabular}{l}
\hline Liver failure \\
\hline Respiratory failure \\
\hline Severe infection \\
\hline Ketoacidosis \\
\hline Pregnancy (according to the SPC) \\
\hline
\end{tabular}

\section{Table II. Favourable effects of metformin}

\begin{tabular}{l}
\hline Metformin \\
\hline $\begin{array}{l}\text { Does not stimulate secretion of insulin (thus it does not generate } \\
\text { hypoglycaemia) }\end{array}$ \\
\hline Inhibits hepatic production of glucose \\
\hline Augments peripheral uptake of glucose \\
\hline Reduces the demand for insulin \\
\hline Is present, at a high concentration, in the intestinal mucosa \\
\hline Affects the intestinal flora (among others, it acts on the metabolism of \\
folates and methionine, which delays ageing in nematodes and rodents) \\
\hline Has a favourable effect on the cardiovascular system and lipid \\
metabolism \\
\hline Has a neutral effect on body weight \\
\hline Probably has an anti-cancer effect \\
\hline
\end{tabular}

to other tissues, which may explain the occurrence of gastrointestinal adverse effects with the use of this drug in some patients $[15,16]$. Additionally, metformin accumulation in the intestinal mucosa may interfere with FDG (18F-deoxyglucose) PETCT image assessment (see below). Furthermore, metformin use is associated with a change in intestinal flora composition, and in particular with and increased amount of a Gram-negative anaerobic bacteria - Akkermansia muciniphila (belonging to 
Verrucomicrobia), residing in the intestine, within the mucous membrane. These bacteria are specialised in the degradation of mucin (a glycoprotein found in the mucus). According to the most recent data, the Akkermansia bacteria not only improve the function of the intestinal barrier but they also increase the number of regulatory T cells (Treg) and reduce mild inflammation present in the fatty tissue of obese experimental animals [17, 18];

- Metformin, via activation of AMPK, followed by phosphorylation of the Unc-51-like kinase 1 (ULK-1) and beclin 1, also initiates autophagy [19]. Autophagy is a katabolic process during which macromolecular components of the cytoplasm are destroyed. Initially, part of the cytoplasm is surrounded by a double membrane that finally forms a follicle - autophagosome. The autophagosome unites with a lysosome and is digested. Autophagy is necessary for the maintenance of the intracellular balance, thus enabling survival of the cells under stress conditions. It seems that metformin-induced increased autophagic activity may result in an improvement of the metabolic profile in stress conditions, and this may lead, among others, to reduction of the mild inflammation that accompanies obesity;

- Some data suggest that this drug prolongs the survival of Caenorhabditis elegans (a type of nematode), which probably is the result of metabolism of folates and methionine changed by metformin (reduced methionine availability in the intestine). Similar observations were made with experimental rodents [20, 21].

\section{Clinical effects during metformin use in diabetic patients}

From the clinical point of view, it is important that metformin reduces the demand for insulin (including the exogenous forms) by improving sensitivity of peripheral tissues to this hormone and by reducing hepatic glucose production. Metformin does not stimulate hypoglycaemia, so it is a safe drug in this respect. This is particularly important in patients with cardiovascular risk, in whom stress reaction of the body in response to glucose level decreased below the recommended range may trigger myocardial infarction or dangerous arrhythmias. Metformin is a completely safe drug if it is used in patients without contraindications to this treatment (Table III).

Metformin has also a number of proven favourable effects other than carbohydrate metabolism, which is very important in the case of diabetic patients, who often have macroangiopathic complications (atheromatosis and its consequences).
Additional effects of metformin:

- neutral effect on the body weight or its reduction, primarily through reduction of the visceral fatty tissue [22];

- cardioprotective: in the studies of UKPDS and UKPDS 10 years later, metformin use was associated with a $30 \%$ reduction of the risk of myocardial infarction. This drug has a favourable effect on the vascular wall through activation of the endothelial NO synthase. It has also a favourable influence on clotting system parameters: plasminogen activator inhibitor 1 (PAI-1) and von Willebrand factor levels are decreased, and the activity of the tissue activator of plasminogen is increased [23, 24].

- improvement of lipidogram: decreased LDL cholesterol and TG levels, increased HDL cholesterol level [4];

- probable anti-cancer effect: AMPK activated with participation of metformin inhibits the mTOR (a threonine-serine protein kinase), which leads to inhibition of proliferation of tumour cells and thus inhibits its growth [25]. Ongoing clinical studies (about 100) will evaluate the effect of metformin on the survival of cancer patients, both with local and with metastatic disease. There are works suggesting a benefit from use of metformin as an adjuvant therapy during chemotherapy [26]. The use of metformin in diabetic patients, irrespective of whether the purpose of drug administration is only diabetes treatment or the drug is used as an add-on therapy in cancer patients, may affect interpretation of the PET scan (positron emission tomography) and thus the staging of the neoplastic disease (see below).

\section{The effect of metformin on PET imaging}

Positron emission tomography (PET) is at present a basic tool in molecular imaging because it provides information about metabolic processes and organ function. PET in combination with computed tomography (PET-CT) allows imaging of both anatomy (computed tomography assures a high spatial resolution) and physiology (functional imaging) owing to fusion of PET and CT images with use of the appropriate software. The capabilities of the positron emission tomography are currently used mainly in oncology, but also in neurology (Alzheimer's disease, epilepsy), cardiology (diagnosis of coronary artery disease), and in imaging of infections and inflammatory conditions (fever of unknown background, immunocompromised patient). PET imaging uses various radiopharmaceuticals that are metabolic molecules and are labelled with radioactive isotopes emitting positrons during their decay (particles of the 
same weight as electrons but positively charged). Fluor 18 (F-18) is currently most commonly used for labelling. A PET gamma camera detects photons of gamma radiation created during annihilation of positrons and electrons, and the picture is reconstructed based on this phenomenon. Glucose labelled with radioactive fluorine is a metabolic tracer widely used in the assessment of neoplastic processes with PET (synonyms: FDG, 18F-FDG, 2 [fluorine-18] fluoro-2-deoxy-d-glukose). It is a glucose analogue with a tendency for higher accumulation in the tissues with increased metabolic activity, e.g. cancer cells (enhanced mitosis, increased activity of glucose transport mechanisms). FDG-glucose is taken up by GLUT transporters in the cell membrane (competing with glucose) and after it gets into the cells and gets phosphorylated (to 6-phosphate FDG) during the first reaction of the Krebs cycle, and is captured in the cells because it is not further metabolised as "normal" glucose. Owing to this fact, FDG concentration in some tumours is higher than in a healthy tissue. FDG is an unspecific tracer, so it accumulates in the region of the highest metabolic activity (benign and malignant tumours, inflammatory foci) [27]. Therefore, differentiation of whether increased tracer uptake is related to a neoplastic process or not remains a problem in PET image interpretation. Furthermore, FDG distribution in the body is affected, among others, by metabolic activity of the tissues - their blood supply and glycolysis rate (brain accumulates more FDG), blood glucose and insulin levels, or muscle activity. As presented above, metformin use is associated with AMPK activation, and some metabolic processes are down-regulated and others are activated. This drug also affects the insulin level. Based on previous data, it is known that changes in glucose metabolism and proliferative activity of the cells may affect FDG uptake. There are not many publications concerning the effects of glucose metabolism modulators, including metformin, on PET-CT imaging in cancer patients. One of these works showed the presence of a reversible increase of intestinal FDG uptake during metformin therapy, which significantly affected interpretation of the image. According to the authors of this work, the diagnostic effectiveness of PET-CT scans is particularly limited by intense diffuse 18F-FDG uptake within the colon, and to a lesser extent - within the small intestine. This may mask the presence of a neoplastic process within the gastrointestinal tract and the actual response of the body to chemotherapy [28]. A recent study, in which human and murine colorectal cancer cells incubated with metformin were assessed, has shown that the effect of this drug on 18F-FDG uptake by the tumour varies from the effect of other, typical chemotherapeutic agents. Under the influence of metformin, cellular uptake of 18F-FDG increases (the patient may be considered a non-responder), and then, due to the death of tumour cells (the result of metformin/chemotherapy administration), 18F-FDG uptake decreases. Such a two-phase response may interfere with the assessment of the efficacy of anticancer therapy. On the other hand, one should bear in mind that even if the volume of the tumour decreases, increased 18F-FDG uptake (due to chronic activation of AMPK) may impede accurate assessment. Use of a proliferation marker, 18F-tymidine (18F-FLT), instead of a cell metabolism marker, such as 18F-FDG, seems to be a better solution for the assessment of treatment efficacy in patients using glucose modulators, such as metformin. The uptake of this tracer correlates well with tumour response to metformin - decreased tumour proliferation $=$ decreased 18F-FLT accumulation [29]. This tracer is not commonly used. In the face of the fact that currently FDG is usually used in PET scans, and metformin is the most commonly prescribed anti-diabetic drug, it should be discontinued before the examination so that it does not interfere with image interpretation. There is no unequivocal opinion among researchers as to a specific wash-out period; however, some authors suggest that metformin should be discontinued in oncological patients at least 48 hours before the scan [28].

As well as the effect of metformin on AMPK and thus on tumour proliferation, it seems that this drug may show anti-cancer activity also through its effect on insulin levels. In a study using murine colorectal cancer cells, exposition to metformin had no effect on the insulin level or FDG uptake by tumour cells in normoinsulinaemic mice, but a decrease of insulin levels and FDG uptake in mice with baseline hyperinsulinaemia was found. The authors suggest that the above effect of metformin use should be taken into consideration in the evaluation of its anticancer activity because the response may depend on whether we have a patient with hyperinsulinaemia and an insulin-sensitive tumour or not [30]. Further improvement of understanding of the effect of metformin (as a drug used in chronic treatment of diabetes or as adjuvant therapy in clinical studies in oncological patients) on FDG uptake and PET image interpretation is necessary. Furthermore, based on the information presented above, a question arises whether FDG is an appropriate marker in the assessment of anticancer activity of metformin [31].

\section{Established clinical applications of metformin other than type 2 diabetes}

\section{Prediabetes}

Before overt diabetes appears, frequently for many years we have to do with a minor elevation of glycaemia values resulting from growing resistance to insulin and 
concomitant compensatory hyperinsulinaemia. This is so-called prediabetes. Prediabetes is defined as: impaired fasting glucose (IFG) (glucose levels: $100-125 \mathrm{mg} / \mathrm{dL}$ ) or impaired glucose tolerance (IGT) diagnosed based on the result of the oral glucose loading test $75 \mathrm{~g}$ (glucose levels at two hours: $\geq 140$ and $\leq 199$, according to the WHO), or both these abnormalities at the same time. Impaired fasting glucose and impaired glucose tolerance are not benign conditions. Patients with these abnormalities have a high risk of both type 2 diabetes development and cardiovascular complications. According to recent data, prediabetes affects 344 million people all over the world, and this number is steadily increasing [32].

Benefits from metformin use in people with prediabetes were shown in a three-year study: the Diabetes Prevention Program (DPP). The use of metformin reduced the risk of type 2 diabetes occurrence by $31 \%$, and change of the lifestyle alone (without medication) by as much as $58 \%$. Body weight reduction was also highest in the behavioural therapy group $(-5.6$ $\mathrm{kg}$ ), and patients using metformin (at the dose of $2 \times$ $850 \mathrm{mg} / 24 \mathrm{~h}$ ) reduced their body weight by $2 \mathrm{~kg}$, as compared to a reduction by $0.1 \mathrm{~kg}$ in the placebo group [33]. By inhibiting hepatic glucose production, which takes place mainly during the night hours, metformin improves fasting glycaemia, which translates into a reduction of cardiovascular complications. There is also data suggesting that use of metformin in patients with IGT is associated with reduction of blood pressure and of hs-CRP levels [34]. According to the guidelines of the Polish Diabetes Association, people diagnosed with prediabetes (IFG or IGT) should be instructed to reduce their body weight and to increase physical activity. Additionally, the start of metformin should be considered as a prevention of type 2 diabetes occurrence in people with high risk of its development, in particular in patients with cardiac risk factors unable (unwilling) to modify their lifestyle.

\section{Insulin resistance and metabolic syndrome}

Insulin resistance means the absence of appropriate response of the body to insulin. Insulin resistance may precede development of type 2 diabetes by many years. This is a condition where both endogenous and exogenous insulin do not have an appropriate effect on glucose uptake and utilisation, as they would in healthy people.

Insulin resistance is promoted, among others, by disturbances of expression of proteins involved in the insulin action pathway and visceral obesity. Adipocytes of the visceral fatty tissue are large and have a higher metabolic activity. They are also less sensitive to insulin [35]. The most important feature of insulin resistance of the fatty tissue is reduced inhibition of lipolysis by insulin, which results in increased levels of free fatty acids. The excess of free fatty acids reduces muscle glucose uptake and leads to disturbances in insulin signalling. Sensitivity to insulin decreases also naturally along with advancing age, probably as a result of the increase in the amount of the visceral fatty tissue and of the levels of proinflammatory factors as well as triacylglycerol deposition in cells [4]. Insulin resistance may lead to development of prediabetes, type 2 diabetes, metabolic syndrome, and PCOS. Insulin resistance/overt type 2 diabetes is one of the components of metabolic syndrome [36, 37]. Based on data regarding the pleiotropic activity of metformin, its use in the above conditions is highly justified. By reducing insulin resistance and thus reducing compensatory hyperinsulinaemia, metformin is the chance to delay type 2 diabetes onset.

Insulin resistance may also be of secondary nature and it may occur in the course of such conditions as: liver cirrhosis, cancers, autoaggressive diseases, uraemia, and endocrinopathies: Cushing syndrome, acromegaly, or pheochromocytoma [4].

Not only an excess but also a deficit of fatty tissue leads to insulin resistance, which is observable in lipodystrophy (lipoatrophy) syndromes. In these conditions metformin is also used [38, 39].

\section{Polycystic ovary syndrome}

A compensatory hyperinsulinaemia, secondary to insulin resistance, occurs usually in PCOS, which seems to be important for hyperandrogenism development because it leads to stimulation of the cells of the follicles that express receptors for IGF-1 and insulin. Insulin may modify LH receptors on the thecal cells of the follicles, thus contributing to increased androgenesis. Consequently, resistance of peripheral tissues to insulin and increased sensitivity of the ovary to insulin occur concurrently. Besides, hyperinsulinaemia decreases the levels of the IGF binding protein (IGFBP-1), which results in increased levels of available IGF-1, which enhances LH stimulation of the ovary to androgen production [40]. Increased levels of insulin are also associated with decreased levels of sex hormone binding globulin (SHGB), which results in an excess of active testosterone. It was shown that insulin resistance affects not only obese but also slim women with PCOS [41, 42]. Patients with polycystic ovary syndrome have an increased risk of development of metabolic syndrome and its consequences, in the form of cardiovascular complications, prediabetes, and type 2 diabetes. Metformin has had its place in the treatment of polycystic ovary syndrome for many years. This drug, by reducing insulin resistance in the PCOS patients, has a favourable effect on fertility, regulates menstrual periods, decreases hirsutism, and may lead to body weight reduction [42]. Metformin is 
also related with significant decreases in proinsulin and androstenedione levels in obese or overweight PCOS patients [43]. Additionally, it improves lipid metabolism parameters and lowers CRP levels. Combined treatment with clomiphene citrate and metformin improves ovulation frequency and thus increases the number of pregnancies. So this drug is used both in the treatment of PCOS symptoms and in the treatment of infertility [44]. Decreased incidence of spontaneous abortions, obstetric complications, and of congenital defects in the foetus were found in PCOS patients using metformin before and during pregnancy, as well as a lower risk of gestational diabetes mellitus (GDM) development [45, 46]. It should be stressed that metformin use does not release PCOS patients from the necessity to modify their lifestyle (appropriate diet and physical activity).

\section{Conclusions}

Metformin is the most frequently prescribed oral antidiabetic drug in the world. Its position in the treatment of type 2 diabetes has been established for over two decades. For many years this drug has also been used in the treatment of prediabetes, of the polycystic ovary syndrome, and of insulin resistance conditions. Additional, favourable effects of the drug on the cardiovascular system as well as its frequently suggested anti-cancer activity further justify the presence of metformin at each level of the algorithm of type 2 diabetes treatment in national and global recommendations of diabetes associations. Images obtained with PET scans using FDG as the radiotracer represent a tangible effect of drug interference with glucose and cancer metabolism. One should, however, bear in mind the fact that chronic intake of metformin by patients with type 2 diabetes, as well as by oncological patients (as adjuvant therapy), significantly affects interpretation of the obtained image. Therefore, the drug should be discontinued for an adequate time period before the scan. Numerous studies are currently ongoing that will certainly enlarge our knowledge about the mechanisms of action of metformin and will give us the final answer to the question of whether the drug has a real anti-cancer effect in humans and whether prolonged survival of treated nematodes and rodents may translate into a similar effect in primates.

\section{References}

1. Inzucchi SE, Bergenstal RM, Buse JB, et al. Management of hyperglycaemia in type 2 diabetes: a patient-centered approach. Position statement of the American Diabetes Association (ADA) and the European Association for the Study of Diabetes (EASD). Diabetologia. 2012; 55(6): 1577-1596, doi: 10.1007/s00125-012-2534-0.

2. Polskie Towarzystwo Diabetologiczne. Zalecenia kliniczne dotyczące postępowania z chorym na cukrzycę 2016. Diabetol Klin. 2016; 2(supl. A).
3. Stumvoll M, Nurjhan N, Perriello G, et al. Metabolic effects of metformin in non-insulin-dependent diabetes mellitus. N Engl J Med. 1995; 333(9): 550-554, doi: 10.1056/NEJM199508313330903, indexed in Pubmed: 7623903.

4. Sieradzki J. Cukrzyca. Via Medica, Gdańsk 2006.

5. Owen MR, Doran E, Halestrap AP. Evidence that metformin exerts its anti-diabetic effects through inhibition of complex 1 of the mitochondrial respiratory chain. Biochem J. 2000; 348 Pt 3: 607-614, indexed in Pubmed: 10839993.

6. Hur KY, Lee MS. New mechanisms of metformin action: Focusing on mitochondria and the gut. J Diabetes Investig. 2015; 6(6): 600-609, doi: 10.1111/jdi.12328, indexed in Pubmed: 26543531.

7. Harding HP, Zhang $\mathrm{Y}$, Zeng $\mathrm{H}$, et al. An integrated stress response regulates amino acid metabolism and resistance to oxidative stress. Mol Cell. 2003; 11(3): 619-633, indexed in Pubmed: 12667446.

8. Kim KH, Jeong YT, Oh H, et al. Autophagy deficiency leads to protection from obesity and insulin resistance by inducing Fgf21 as a mitokine. Nat Med. 2013; 19(1): 83-92, doi: 10.1038/nm.3014, indexed in Pubmed: $\underline{23202295}$.

9. Zhang M, Liu Y, Xiong Zy, et al. Changes of plasma fibroblast growth factor-21 (FGF-21) in oral glucose tolerance test and effects of metformin on FGF-21 levels in type 2 diabetes mellitus. Endokrynol Pol. 2013; 64(3): 220-224, indexed in Pubmed: 23873427.

10. Klip A, Leiter LA. Cellular Mechanism of Action of Metformin. Diabetes Care. 1990; 13(6): 696-704, doi: 10.2337/diacare.13.6.696.

11. Madiraju AK, Erion DM, Rahimi Y, et al. Metformin suppresses gluconeogenesis by inhibiting mitochondrial glycerophosphate dehydrogenase. Nature. 2014; 510(7506): 542-546, doi: 10.1038/nature13270, indexed in Pubmed: 24847880.

12. Miller RA, Chu Q, Xie J, et al. Biguanides suppress hepatic glucagon signalling by decreasing production of cyclic AMP. Nature. 2013; 494(7436): 256-260, doi: 10.1038/nature11808, indexed in Pubmed: 23292513.

13. Sieradzki J. Działanie inkretynopodobne metforminy. Diabetologia Praktyczna. 2011; 12: 6-10.

14. Matveyenko AV, Dry S, Cox HI, et al. Beneficial endocrine but adverse exocrine effects of sitagliptin in the human islet amyloid polypeptide transgenic rat model of type 2 diabetes: interactions with metformin. Diabetes. 2009; 58(7): 1604-1615, doi: 10.2337/db09-0058, indexed in Pubmed: 19403868

15. Bailey CJ, Mynett KJ, Page T. Importance of the intestine as a site of metformin-stimulated glucose utilization. Br J Pharmacol. 1994; 112(2): 671-675, indexed in Pubmed: 8075887.

16. Bailey CJ, Wilcock C, Scarpello JHB. Metformin and the intestine. Diabetologia. 2008; 51(8): 1552-1553, doi: 10.1007/s00125-008-1053-5, indexed in Pubmed: 18528677.

17. Shin NR, Lee JC, Lee HY, et al. An increase in the Akkermansia spp. population induced by metformin treatment improves glucose homeostasis in diet-induced obese mice. Gut. 2014; 63(5): 727-735, doi: $10.1136 /$ gutjnl-2012-303839, indexed in Pubmed: 23804561.

18. Derrien M, Van Baarlen P, Hooiveld G, et al. Modulation of Mucosal Immune Response, Tolerance, and Proliferation in Mice Colonized by the Mucin-Degrader Akkermansia muciniphila. Front Microbiol. 2011; 2: 166, doi: $10.3389 /$ fmicb.2011.00166, indexed in Pubmed: 21904534.

19. Egan DF, Shackelford DB, Mihaylova MM, et al. Phosphorylation of ULK1 (hATG1) by AMP-activated protein kinase connects energy sensing to mitophagy. Science. 2011; 331(6016): 456-461, doi: 10.1126/ science.1196371, indexed in Pubmed: 21205641.

20. Houtkooper RH, Mouchiroud L, Ryu D, et al. Mitonuclear protein imbalance as a conserved longevity mechanism. Nature. 2013; 497(7450): 451-457, doi: $10.1038 /$ nature12188, indexed in Pubmed: 23698443.

21. Martin-Montalvo A, Mercken EM, Mitchell SJ, et al. Metformin improves healthspan and lifespan in mice. Nat Commun. 2013; 4: 2192, doi: 10.1038/ncomms3192, indexed in Pubmed: 23900241.

22. Kurukulasuriya R, Banerji MA, Chaiken R, et al. Selective decrease in visceral fat is associated with weight loss during metformin treatment in African Americans with type 2 diabetes. Diabetes. 1999; 48: 315.

23. Intensive blood-glucose control with sulphonylureas or insulin compared with conventional treatment and risk of complications in patients with type 2 diabetes (UKPDS 33). The Lancet. 1998; 352(9131): 837-853, doi: $\underline{10.1016 / \mathrm{s} 0140-6736(98) 07019-6}$.

24. Holman RR, Paul SK, Bethel MA, et al. 10-year follow-up of intensive glucose control in type 2 diabetes. N Engl J Med. 2008; 359(15): 1577-1589, doi: 10.1056/NEJMoa0806470, indexed in Pubmed: 18784090 .

25. Liu B, Fan Z, Edgerton SM, et al. Potent anti-proliferative effects of metformin on trastuzumab-resistant breast cancer cells via inhibition of erbB2/IGF-1 receptor interactions. Cell Cycle. 2011; 10(17): 2959-2966, doi: 10.4161/cc.10.17.16359, indexed in Pubmed: 21862872.

26. Rocha GZ, Dias MM, Ropelle ER, et al. Metformin amplifies chemotherapy-induced AMPK activation and antitumoral growth. Clin Cancer Res. 2011; 17(12): 3993-4005, doi: 10.1158/1078-0432.CCR-10-2243, indexed in Pubmed: 21543517 
27. Brant WE, Helms CA. Podstawy diagnostyki radiologicznej. Lippincott Williams \& Wilkins, Philadelphia 2007.

28. Steenkamp DW, McDonnell ME, Meibom S. Metformin may be associated with false-negative cancer detection in the gastrointestinal tract on PET/CT. Endocr Pract. 2014; 20(10): 1079-1083, doi: 10.4158/EP14127.RA indexed in Pubmed: 25100379.

29. Habibollahi P, van den Berg NS, Kuruppu D, et al. Metformin--an adjunct antineoplastic therapy--divergently modulates tumor metabolism and proliferation, interfering with early response prediction by 18F-FDG PET imaging. J Nucl Med. 2013; 54(2): 252-258, doi: 10.2967 jnumed.112.107011, indexed in Pubmed: 23376854

30. Mashhedi $\mathrm{H}$, Blouin MJ, Zakikhani M, et al. Metformin abolishes increased tumor (18)F-2-fluoro-2-deoxy-D-glucose uptake associated with a high energy diet. Cell Cycle. 2011; 10(16): 2770-2778, doi: 10.4161/ cc.10.16.16219, indexed in Pubmed: 21811094.

31. Capitanio S, Marini C, Sambuceti G, et al. Metformin and cancer: Technical and clinical implications for FDG-PET imaging. World J Radiol. 2015; 7(3): 57-60, doi: 10.4329/wjr.v7.i3.57, indexed in Pubmed: 25825634.

32. www.diabetesatlas.com.

33. Knowler WC, Barrett-Connor E, Fowler SE, et al. Reduction in the Incidence of Type 2 Diabetes with Lifestyle Intervention or Metformin. New England Journal of Medicine. 2002; 346(6): 393-403, doi: 10.1056/ nejmoa012512.

34. Malin SK, Nightingale J, Choi SE, et al. Metformin modifies the exercise training effects on risk factors for cardiovascular disease in impaired glucose tolerant adults. Obesity (Silver Spring). 2013; 21(1): 93-100, doi 10.1002/oby.20235, indexed in Pubmed: 23505172.

35. Kershaw EE, Flier JS. Adipose tissue as an endocrine organ. J Clin Endocrinol Metab. 2004; 89(6): 2548-2556, doi: 10.1210/jc.2004-0395, indexed in Pubmed: 15181022.

36. Alberti KG, Eckel RH, Grundy SM, et al. International Diabetes Federation Task Force on Epidemiology and Prevention, Hationa Heart, Lung, and Blood Institute, American Heart Association, World Heart Federation, International Atherosclerosis Society, Internationa Association for the Study of Obesity. Harmonizing the metabolic syndrome: a joint interim statement of the International Diabete Federation Task Force on Epidemiology and Prevention; National Heart, Lung, and Blood Institute; American Heart Association; World Heart Federation; International Atherosclerosis Society; and Interna- tional Association for the Study of Obesity. Circulation. 2009; 120(16): 1640-1645, doi: 10.1161/CIRCULATIONAHA.109.192644, indexed in Pubmed: 19805654

37. Grundy SM. Pre-diabetes, metabolic syndrome, and cardiovascular risk J Am Coll Cardiol. 2012; 59(7): 635-643, doi: 10.1016/j.jacc.2011.08.080, indexed in Pubmed: 22322078

38. Jain SS, Ramteke KB, Raparti GT, et al. Pathogenesis and treatment of human immunodeficiency virus lipodystrophy. Indian J Endocrinol Metab. 2012; 16 Suppl 1: S20-S26, doi: 10.4103/2230-8210.94250, indexed in Pubmed: 22701839.

39. Lewandowski KC, Lewiński A, Dąbrowska K, et al. Familial partial lipodystrophy as differential diagnosis of polycystic ovary syndrome. Endokrynol Pol. 2015; 66(6): 550-554, doi: 10.5603/EP.2015.0067, indexed in Pubmed: 26662654

40. Dunaif A. Insulin resistance and the polycystic ovary syndrome: mechanism and implications for pathogenesis. Endocr Rev. 1997; 18(6): 774-800 doi: 10.1210/edrv.18.6.0318, indexed in Pubmed: 9408743.

41. Marx TL, Mehta AE. Polycystic ovary syndrome: pathogenesis and treatment over the short and long term. Cleve Clin J Med. 2003; 70(1): 31-33, 36-41, 45, indexed in Pubmed: 12549723.

42. Milewicz A. Endokrynologia kliniczna. Polskie Towarzystwo Endokrynologiczne, Wrocław 2012

43. Kruszyńska A, Słowińska-Srzednicka J, Jeske W, et al. Proinsulin, adiponectin and hsCRP in reproductive age women with polycystic ovary syndrome (PCOS) - the effect of metformin treatment. Endokrynol Pol 2014; 65(1): 2-10, doi: 10.5603/EP.2014.0001, indexed in Pubmed: 24549596.

44. Vandermolen DT, Ratts VS, Evans WS, et al. Metformin increases the ovulatory rate and pregnancy rate from clomiphene citrate in patients with polycystic ovary syndrome who are resistant to clomiphene citrate alone. Fertil Steril. 2001; 75(2): 310-315, indexed in Pubmed: 11172832.

45. Lord JM, Flight IHK, Norman RJ. Insulin-sensitising drugs (metformin troglitazone, rosiglitazone, pioglitazone, $\mathrm{D}$-chiro-inositol) for polycystic ovary syndrome. Cochrane Database Syst Rev. 2003(3): CD003053, doi 10.1002/14651858.CD003053, indexed in Pubmed: 12917943.

46. Glueck CJ, Goldenberg N, Pranikoff J, et al. Effects of metformin-diet intervention before and throughout pregnancy on obstetric and neonatal outcomes in patients with polycystic ovary syndrome. Curr Med Res Opin. 2013; 29(1): 55-62, doi: 10.1185/03007995.2012.755121, indexed in Pubmed: 23205605. 


\title{
Metformina - nowy stary lek
}

\author{
Marta Patrycja Wróbel', Bogdan Marek², Dariusz Kajdaniuk², Dominika Rokicka', \\ Aleksandra Szymborska-Kajanek ${ }^{1}$, Krzysztof Strojek ${ }^{1}$
}

${ }^{1}$ Oddział Kliniczny Chorób Wewnętrznych, Diabetologii i Schorzeń Kardiometabolicznych Wydział Lekarski z Oddziatem LekarskoDentystycznym w Zabrzu, Śląski Uniwersytet Medyczny w Katowicach, Śląskie Centrum Chorób Serca, Zabrze, Polska

${ }^{2}$ Katedra Patofizjologii i Endokrynologii, Wydziat Lekarski z Oddziałem Lekarsko-Dentystycznym w Zabrzu, Ślaski Uniwersytet Medyczny w Katowicach, Polska

Artykuł jest tłumaczeniem pracy: Wróbel M.P., Marek B., Kajdaniuk D., Rokicka D., Szymborska-Kajanek A., Strojek K. Metformin — a new old drug. Endokrynol Pol 2017; 68 (4): 482-489

Należy cytować wersję pierwotną.

Piśmiennictwo dostępne w wersji pierwotnej na stronach $488-489$

\section{Streszczenie}

Od lat metformina jest złotym standardem w leczeniu cukrzycy typu 2. Według rekomendacji najważniejszych towarzystw diabetologicznych jest to lek pierwszego wyboru do stosowania w monoterapii u chorych ze świeżo rozpoznaną cukrzycą typu 2. Jest ona również zalecana $\mathrm{w}$ terapii skojarzonej cukrzycy $\mathrm{w}$ połączeniu z pochodną sulfonylomocznika, lekiem inkretynowym, flozyną czy insuliną, niezależnie od ilości wstrzyknięć na dobę. Metformina oprócz właściwości wykorzystywanych w leczeniu cukrzycy, od pewnego czasu traktowana jest jako lek o tak zwanym działaniu plejotropowym, szczególnie, że z każdym rokiem pojawiają się nowe doniesienia o jej korzystnym wpływie na inne zaburzenia. Obecnie metformina ma rozszerzony zakres wskazań objętych refundacją o stan przedcukrzycowy, zespoły insulinooporności oraz zespół policystycznych jajników. Lek ten nie stymuluje wydzielania insuliny przez komórki beta trzustki, tym samym nie powoduje hipoglikemii. Działanie leku obniżające stężenie glukozy we krwi jest między innymi następstwem hamowania wątrobowej produkcji glukozy oraz uwrażliwiania tkanek obwodowych (tk. mięśniowa, tk. tłuszczowa) na działanie insuliny zarówno endogennej jak i podawanej z zewnątrz. Przez długi czas nie było wiadomo jaki jest dokładny mechanizm działania metforminy na poziomie komórki. Badania przeprowadzone w ciągu ostatnich lat dostarczyły wielu informacji, które pozwalają lepiej zrozumieć sposób działania leku oraz efekty kliniczne wynikające z jego stosowania. Metformina poza poprawą glikemii, ma neutralny wpływ na masę ciała, działa kardioprotekcyjne, poprawia parametry lipidowe, a także podejrzewa się, że wykazuje działanie przeciwnotworowe. Jej gromadzenie w obrębie błony śluzowej jelit może dodatkowo zaburzać ocenę obrazu PET-TK z wykorzystaniem 18F-dezoksy-glukozy (FDG). Celem artykułu jest szczegółowe omówienie właściwości metforminy, jej mechanizmów działania oraz efektów klinicznych terapii. Endokrynol Pol 2017; 68 (4): 490-496)
\end{abstract}

Słowa kluczowe: metformina; właściwości metforminy; cukrzyca typu 2

\section{Wprowadzenie}

Od późnych lat 90-tych metformina jest złotym standardem w leczeniu cukrzycy typu 2. Jest to lek pierwszego wyboru do stosowania $\mathrm{w}$ monoterapii $\mathrm{u}$ chorych ze świeżo rozpoznaną cukrzycą typu 2 , według rekomendacji najważniejszych towarzystw diabetologicznych. Metformina jest również zalecana w terapii skojarzonej, kiedy monoterapia przestaje być skuteczna. Jest ona wtedy łączona z pochodną sulfonylomocznika lub lekiem inkretynowym, flozyną czy insuliną niezależnie od ilości wstrzyknięć na dobę [1,2]. Metformina jest jedynym powszechnie dostępnym ze względów ekonomicznych preparatem, który oprócz działania obniżającego glikemię, ma korzystny wpływ na masę ciała.
Ma to istotne znaczenie, ponieważ populacja chorych na cukrzycę to zazwyczaj osoby z nadmierą masą ciała. Metformina oprócz właściwości wykorzystywanych w leczeniu cukrzycy od pewnego czasu traktowana jest jako lek o tak zwanym plejotropowym działaniu, szczególnie, że z każdym rokiem pojawiają się nowe doniesienia o jej korzystnym wpływie w inne zaburzenia $[3,4]$. Obecnie lek ma rozszerzony zakres wskazań objętych refundacją o stan przedcukrzycowy, zespoły insulinooporności oraz zespół policystycznych jajników.

\section{Mechanizm działania metforminy}

Metformina nie stymuluje wydzielania insuliny przez komórki beta trzustki, tym samym jest lekiem nie

Marta Patrycja Wróbel M.D., Ph.D., Oddział Kliniczny Chorób Wewnętrznych, Diabetologii i Schorzeń Kardiometabolicznych SUM, Śląskie Centrum Chorób Serca, ul. Curie-Skłodowskiej 9, 41-800 Zabrze, Polska, tel.: 3237338 23, e-mail: mwrobel@sum.edu.pl 
powodującym hipoglikemii. Działanie leku obniżające stężenie glukozy we krwi jest następstwem hamowania wątrobowej produkcji glukozy oraz uwrażliwiania tkanek obwodowych (tkanka mięśniowa, tkanka tłuszczowa) na działanie insuliny zarówno endogennej, jak i podawanej z zewnątrz. Przez długi czas nie było wiadomo jaki jest dokładny mechanizm działania metforminy na poziomie komórki. Badania przeprowadzone w ciągu ostatnich lat dostarczyły wielu informacji, które pozwalają lepiej zrozumieć sposób działania leku oraz efekty kliniczne wynikające z jego stosowania. Poniżej przestawiono obecny stan wiedzy w tym zakresie.

- Metformina zaburza oddychanie komórkowe poprzez hamowanie kompleksu I mitochondrialnego łańcucha oddechowego (stres mitochondrialny), co prowadzi do zmniejszenia ilości wewnątrzkomórkowego ATP, imitując stan głodzenia komórki. Zwiększeniu ulega zatem pula AMP, a to pobudza AMP-kinazę, która jest tak zwanym energetycznym czujnikiem komórki. AMP-kinaza ulega aktywacji nawet przy nieznacznym niedoborze ATP. Prowadzi to do "wyciszenia” (down regulation) wszystkich szlaków metabolicznych, które zużywają energię — proliferacja, synteza białek i lipidów [5]. Z kolei zwiększa się produkcja ATP poprzez nasilony wychwyt glukozy z krwi, zwiększenie glikolizy (tym samym zwiększenie utylizacji glukozy i obniżenie jej stężenia we krwi) oraz beta-oksydacji kwasów tłuszczowych. Cząsteczki AMP aktywują AMPK (AMP- kinaza) bezpośrednio poprzez przyłączenie się do podjednostki gamma enzymu lub pośrednio poprzez hamowanie jego defosforylacji. Pobudzenie AMP kinazy zwiększa również translokację transporterów dla glukozy — GLUT — w kierunku błony komórkowej i nasila jej transport do wnętrza komórki (zwiększona utylizacja glukozy) (ryc. 1 i tab. I) [6].

- Na podstawie wyników ostatnich badań okazuje się, że metformina wykazuje również działanie niezależne od pobudzenia AMP kinazy. Hamując kompleks I mitochondrialnego łańcucha oddechowego prowadzi do produkcji wolnych rodników tlenowych (ROS - reactive oxygen species) i generuje tak zwaną zintegrowaną odpowiedź stresową $\mathrm{w}$ mitochondrium (ISR - integrated stress response) dzięki aktywacji transkrypcyjnego czynnika IV (ATF-4 - activating transcription factor-4) , który pobudza FGF-21 (fibroblast growth factor-21, czynnik wzrostu fibroblastów-21) [7, 8]. Szlak ten jest zupełnie niezależny od AMP kinazy, co potwierdziły badania prowadzone na hodowli fibroblastów gryzoni, pozbawionych genu AMP kinazy. FGF-21 produkowany przez komórki wątrobowe uznawany był dotychczas za czynnik zaangażowany jedynie $\mathrm{w}$ metabolizm glukozy i lipidów, jak się okazuje, odgrywa również rolę $\mathrm{w}$ mechanizmie działania metforminy. Zaobserwowano, że stężenie FGF-21 ulega zmianie u osób leczonych metforminą [9].

- Powszechnie wiadomo, że metformina hamuje glukoneogenezę wątrobową [10]. Niemniej, mechanizm działania leku $\mathrm{w}$ tym zakresie został poznany dopiero niedawno. Istnieją dane, które sugerują, że metformina hamuje mitochondrialną mGDP- dehydrogenazę glicerofosforanową - kluczowy enzym łączący szlaki metaboliczne węglowodanów i lipidów (przy czym nie wpływa na cytozolową dehydrogenazę glicerofosforanową - cGDP) [11]. W normalnych warunkach szlak ten pozwala wejść zredukowanej formie $\mathrm{NAD}(\mathrm{NADH}+)$ powstałej $\mathrm{w}$ procesie glikolizy w cytoplazmie do mitochondrium, gdzie odbywa się produkcja ATP i regeneracja cytoplazmatycznego NAD+. Blokowanie mGDP utrudnia konwersję glicero-3- fosforanu do fosforanu dihydroksyacetonu (DHAP dihydroxyacetone phosphate) i tym samym hamuje glukoneogenezę z glicerolu. Wskutek zmniejszonego stężenia NAD+ (utleniona forma NAD) dochodzi do kumulacji mleczanu, ponieważ $\mathrm{w}$ takich warunkach upośledzona jest jego przemiana do pirogronianu (reakcja katalizowana przez dehydrogenazę mleczanową) oraz dodatkowo zahamowaniu ulega glukoneogeneza wątrobowa [12] (ryc. 1). Gromadzenie mleczanu na poziomie komórki jest typowym zjawiskiem podczas terapii metforminą, niemniej jego ilość nie jest szkodliwa jeśli lek stosowany jest po uwzględnieniu przeciwwskazań do terapii (tab. III).

- Inne wyjaśnienie hamującego wpływu metforminy na glukoneogenezę wątrobową opublikowano kilka lat temu w czasopiśmie "Nature". Za glukoneogenezę wątrobową odpowiedzialny jest również glukagon, którego nadmierna sekrecja przez komórki alfa trzustki u chorych na cukrzycę typu 2, jest jednym z elementów złożonej patogenezy tego schorzenia. Glukagon łącząc się z receptorem na hepatocycie, aktywuje cyklazę adenylową i tym samym promuje powstawanie cAMP (cykliczny AMP), co stymuluje kinazę białkową A (PKA) prowadząc do wątrobowej produkcji glukozy. Autorzy tej pracy twierdzą, że metformina osłabia działanie glukagonu po połączeniu z receptorem poprzez zmniejszenie produkcji cAMP w komórkach wątroby. Dzieje się tak dlatego, że metformina hamując mitochondrialny kompleks 1 łańcucha oddechowego, prowadzi do gromadzenia AMP, a to hamuje cyklazę adenylową i tym samym produkcję cAMP. Zmniejszona ilość cAMP hamuje aktywność kinazy 


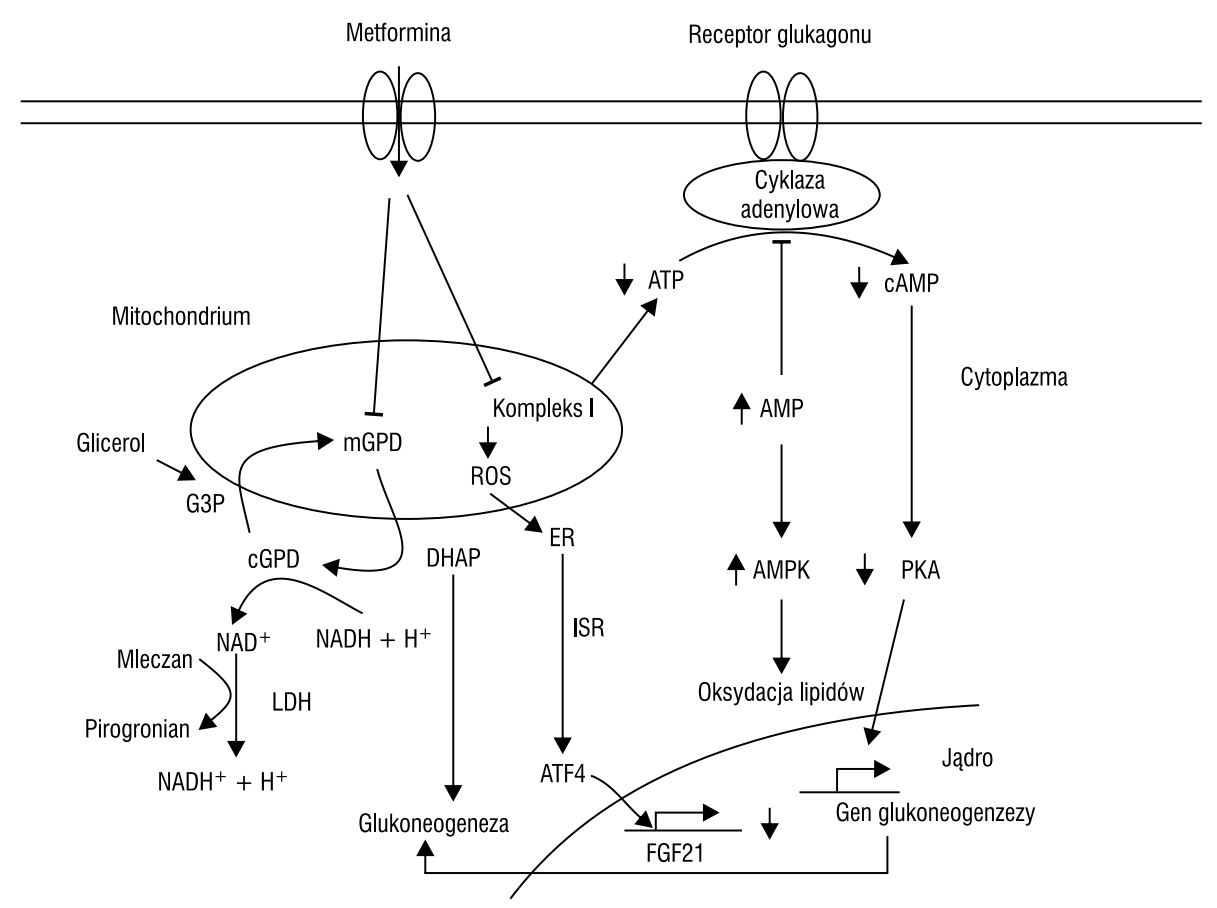

Rycina 1. Mechanizm działania metforminy; Legenda: AMPK — kinaza AMP, ATF-4 — czynnik transkrypcyjny 4, COMPLEX 1 kompleks I mitochondrialnego tańcucha oddechowego, DHAP — fosforanu dihydroksyacetonu, ER — reticulum endoplazmatyczne, FGF21 - czynnik wzrostu fibroblastów-21, G3P-glycerol-3-phosphate, ISR - zintegrowana odpowiedź stresowa, cGPD - cytozolowa dehydrogenaza glicerofosforanowa, $m G D P$ - mitochondrialna dehydrogenaza glicerofosforanowa, PKA — kinaza białkowa A, ROS — wolne rodniki

Tabela I. Skutki pobudzenia AMP kinazy przez metforminę

\section{Na skutek pobudzenia AMP kinazy dochodzi do:}

Zmniejszenia wątrobowej produkcji wątroby (glikogenolizy i glukoneogenezy)

Zwiększenia obwodowego wychwytu i utylizacji glukozy przez mięśnie

Pobudzenia przemieszczania glut w kierunku błony komórkowej, co zwiększa wychwyt glukozy z krwiobiegu

\begin{tabular}{l}
\hline Zmniejszenia lipogenezy \\
\hline $\begin{array}{l}\text { Pobudzenia procesu } \beta \text {-oksydacji (utylizacja wolnych kwasów } \\
\text { tłuszczowych) }\end{array}$ \\
\hline
\end{tabular}

białkowej A (PKA) i w ten sposób osłabia glukoneogenezę wątrobową [13] (ryc. 1).

- Dodatkowo, metformina indukuje sekrecję GLP-1 (glukagonopodobny peptyd-1) przez komórki L jelita cienkiego oraz uwrażliwia komórki beta trzustki na jego działanie wpływając między innymi na ekspresję na nich receptora dla GLP -1 [14, 15]. GLP-1 jest hormonem inkretynowym, którego niedobór lub osłabione działanie odgrywa istotną rolę w patogenezie cukrzycy typu 2. Fizjologicznie GLP-1 jest odpowiedzialny za zwiększenie wydzielania insuliny przez komórki beta trzustki w odpowiedzi na spożyty pokarm. GLP-1 łącząc się z właściwym dla siebie receptorem na komórce beta (innym
Tabela II. Korzystne działanie metforminy

\begin{tabular}{l}
\hline Metformina \\
\hline Nie stymuluje wydzielania insuliny (tym samym nie generuje hipoglikemii) \\
\hline Hamuje wątrobową produkcję glukozy \\
\hline Zwiększa wychwyt obwodowy glukozy \\
\hline Zmniejsza zapotrzebowanie na insulinę \\
\hline Obecna jest w dużym stężeniu w błonie śluzowej jelita \\
\hline Ma wpływ na florę jelitową (między innnymi na metabolizm folianów \\
i metioniny $\rightarrow$ opónienie starzenia u nicieni i gryzoni) \\
\hline Ma korzystny wpływ na układ sercowo-naczyniowy i gospodarkę \\
lipidową \\
\hline Ma neutralny wpływ na masę ciała \\
\hline Prawdopodobnie działa przeciwnowotworowo
\end{tabular}

niż dla pochodnej sulfonylomocznika) stymuluje wyrzut insuliny dostosowany do stężenia glukozy we krwi, nie generując tym samym hipoglikemii. Ze względu między innymi na bezpieczeństwo terapii (minimalne ryzyko hipoglikemii) leki poprawiające osłabiony w cukrzycy efekt inkretynowy (tak zwane leki inkretynowe) są coraz szerzej stosowane $\mathrm{w}$ terapii cukrzycy typu 2. Należą do nich analogi GLP-1 (agoniści receptora dla GLP-1 na komórkach beta trzustki) oraz inhibitory dipeptydylo-peptydazy 4 - enzymu odpowiedzialnego 
Tabela III. Przeciwwskazania do stosowania metforminy

\begin{tabular}{l} 
Przeciwwskazaniem do stosowania metforminy są wszystkie \\
stany hipoksji \\
\hline Niewydolność nerek (zwykle przy GFR < 60 ml/min lek należy \\
odstawić lub zmniejszyć dawkę - obowiązuje postępowanie \\
zgodne z charakterystyką produktu leczniczego (ChPI). Według \\
charakterystyki produktu leczniczego Glucophage — lek może \\
być stosowany u chorych z umiarkowaną niewydolnością nerek \\
(GFR 45-59 ml/min/ 1,73 m²) jeżeli nie występują inne czynniki \\
zwiększające ryzyko kwasicy mleczanowej; stosuje się mniejszą \\
dawkę leku - maksymalnie 1000 mg/dobę w 2 podzielonych \\
dawkach \\
\hline Niewydolność krążenia (zaawansowana - NYHA III, IV), świeży zawat \\
serca, wstrząs \\
\hline Niewydolność wątroby \\
\hline Niewydolność oddechowa \\
\hline Ciężkie zakażenie \\
\hline Kwasica ketonowa \\
\hline Ciąża (zgodnie z ChPI)
\end{tabular}

za rozpad GLP-1. Kojarzenie leku inkretynowego $\mathrm{z}$ metfominą jest zatem $\mathrm{w}$ pełni uzasadnione ze względu na potwierdzony synergizm działania.

- Metformina działa również w obrębie jelit zwiększając wychwyt i utylizację glukozy. Okazuje się, że stężenie metforminy w porównaniu do innych tkanek osiąga największe wartości właśnie w błonie śluzowej jelit, czym po części można tłumaczyć występowanie objawów niepożądanych ze strony przewodu pokarmowego przy stosowaniu leku u niektórych chorych [16, 17]. Gromadzenie metforminy w obrębie błony śluzowej jelit może dodatkowo zaburzać ocenę obrazu PET-TK z wykorzystaniem 18F-dezoksy-glukozy (FDG) (patrz niżej). Ponadto stosowanie metforminy wiąże się ze zmianą składu flory jelitowej, szczególnie ze zwiększeniem ilości Gram-ujemnych bakterii beztlenowych Akkermansia muciniphila (należące do Verrucomicrobia), bytujących w jelicie w obrębie warstwy śluzowej. Bakterie te specjalizują się w degradacji mucyny (glikoproteina zawarta w śluzie). Według najświeższych danych, bakterie Akkermansia nie tylko poprawiają funkcję bariery jelitowej, ale również zwiększają liczbę limfocytów $\mathrm{T}$ regulatorowych (Treg) oraz osłabiają do małego stopnia stan zapalny obecny w tkance tłuszczowej otyłych zwierząt doświadczalnych [18, 19].

- Metformina poprzez aktywację AMP kinazy, a następnie fosforylację ULK-1 (unc-51-like k

— inase 1) i bekliny 1 inicjuje również proces autofagii [20]. Autofagia jest to proces kataboliczny, podczas którego dochodzi do niszczenia wielkocząsteczkowych składników cytoplazmy. Początkowo fragment cytoplazmy zostaje otoczony formującą się podwójną błoną tworzącego się pęcherzyka - autofagosomu. Autofagosom po połączeniu z lizosomem zostaje strawiony. Autofagia jest konieczna do utrzymania równowagi wewnątrzkomórkowej, umożliwiając komórkom przetrwanie w warunkach stresu. Wydaje się, że zwiększenie aktywności autofagii pod wpływem metfrominy może wpływać na poprawę profilu metabolicznego w warunkach stresu, a to może prowadzić m.in. do osłabienia stanu zapalnego małego stopnia, który towarzyszy otyłości.

- Istnieją dane mówiące, że lek ten wydłuża czas życia Caenorhabditis elegans (rodzaj nicienia), co prawdopodobnie jest wynikiem zmienionego przez metforminę metabolizmu folianów i metioniny (zmniejszenie dostępności metioniny w jelicie). Podobne obserwacje dotyczą również gryzoni doświadczalnych [21, 22].

\section{Efekty kliniczne podczas stosowania metforminy u chorych na cukrzyce}

Z klinicznego punktu widzenia istotny jest fakt, że metformina zmniejsza zapotrzebowanie na insulinę (w tym podawaną egzogennie) poprzez poprawę wrażliwości tkanek obwodowych na ten hormon i zmniejszenie wątrobowej produkcji glukozy. Metformina nie stymuluje hipoglikemii, czyli jest w tym względzie lekiem bezpiecznym. Jest to szczególnie ważne u chorych obciążonych kardiologicznie, u których reakcja stresowa organizmu w odpowiedzi na obniżenie wartości glukozy poniżej zalecanego zakresu może wyzwolić zawał serca, czy też groźne zaburzenia rytmu serca. Metformina jest lekiem w pełni bezpiecznym jeśli jest stosowana z uwzględnieniem przeciwwskazań do terapii (tab. III).

Metformina ma szereg udowodnionych korzystnych działań poza gospodarką węglowodanową, co ma duże znaczenie w przypadku chorych na cukrzycę, którzy często obciążeni są powikłaniami makroangiopatycznymi (miażdżyca i jej konsekwencje).

Dodatkowe działania metforminy:

- neutralny wpływ na masę ciała lub jej zmniejszenie przede wszystkim poprzez redukcję trzewnej tkanki tłuszczowej [23];

- kardioprotekcyjne: w badaniach UKPDS, UKPDS 10 lat później - stosowanie metforminy wiązało się z 30 procentową redukcją ryzyka zawału serca. Lek ten ma korzystny wpływ na ścianę naczynia poprzez aktywację śródbłonkowej syntazy NO. Wpływa również korzystnie na parametry układu krzepnięcia: zmniejszenie stężenie PAI-1 (inhibitora aktywatora plazminogenu 1) i czynnika von 
Willebranda oraz zwiększenie aktywności tkankowego aktywatora plazminogenu [24, 25];

- poprawa lipidogramu: obniżenie stężenia cholesterolu LDL i TG, zwiększenie stężenia cholesterolu HDL [4]

- prawdopodobny efekt przeciwnowotworowy: aktywowana przy udziale metforminy AMP- kinaza hamuje kinazę mTOR (kinaza białkowa treoninowo-serynowa), co prowadzi do zahamowania proliferacji komórek w obrębie guza i tym samym zahamowuje jego wzrost [26]. Trwają badania kliniczne (około 100) oceniające wpływ metforminy na przeżycie pacjentów z chorobą nowotworową zarówno w przypadku miejscowo zlokalizowanych raków, jak i nowotworów z przerzutami. Istnieją prace sugerujące korzyści wynikające ze stosowania metforminy jako terapii adjuwantowej przy chemioterapii [27]. Stosowanie metforminy, u pacjentów z cukrzycą niezależnie od tego, czy celem jest jedynie leczenie cukrzycy, czy lek stosowany jest jako terapia dodatkowa u pacjentów z chorobą nowotworową, może wpływać na interpretację badania PET (pozytonowa tomografia emisyjna) tym samym na ocenę zaawansowania choroby nowotworowej (patrz niżej).

\section{Wpływ metforminy na obrazowanie PET}

Pozytonowa tomografia emisyjna (PET) jest obecnie podstawowym narzędziem w obrazowaniu molekularnym, dostarcza bowiem informacji o procesach metabolicznych i czynnościowych. PET w połączeniu z tomografią komputerową (PET-CT) pozwala na obrazowanie zarówno anatomiczne (wysoką rozdzielczość przestrzenną zapewnia tomografia komputerowa), jak i fizjologiczne (czynnościowe), dzięki nałożeniu na siebie obrazów PET i TK przy pomocy oprogramowania komputerowego. Możliwości pozytonowej tomografii emisyjnej wykorzystuje się obecnie przede wszystkim w onkologii, ale również w neurologii (choroba Alzheimera, padaczka), kardiologii (diagnostyka choroby wieńcowej i żywotności mięśnia sercowego) oraz w obrazowaniu zakażeń i zapaleń (gorączka o nieznanym tle, stany obniżonej odporności). W diagnostyce PET wykorzystuje się różne radiofarmaceutyki, będące cząstkami metabolicznymi, które znakowane są izotopami promieniotwórczymi emitującymi podczas własnego rozpadu pozytony (cząstki o takiej samej masie jak elektron, ale o dodatnim ładunku). Obecnie do znakowania najczęściej wykorzystuje się fluor-18 (F-18). Gamma kamera do obrazowania PET wykrywa fotony promieniowania gamma powstałe $\mathrm{w}$ czasie anihilacji pozytonów i elektronów i na tej podstawie rekonstruowany jest obraz. Znacznikiem metabolicznym szeroko wykorzystywanym w ocenie procesów nowotworowych przy pomocy PET jest znakowana promieniotwórczym fluorem glukoza (synonimy: FDG, 18F-FDG, 2 [fluoro-18] fluoro-2-deoksy-D-glukoza). Jest ona analogiem glukozy, wykazującym tendencję do większego gromadzenia w tkankach o zwiększonej aktywności metabolicznej, takich jak na przykład komórki nowotworowe (nasilona mitoza, zwiększona aktywność mechanizmów transportujących glukozę). FDG glukoza jest wychwytywana przez transportery GLUT w błonie komórkowej (konkurując z glukozą), a po dostaniu się do komórek i fosforylacji (do 6-fosforanu FDG) w pierwszej reakcji cyklu Krebsa pozostaje w nich, ponieważ nie jest dalej metabolizowana jak „zwykła” glukoza. Dzięki temu stężenie FDG w niektórych guzach jest większe niż w zdrowej tkance. FDG jest nieswoistym wskaźnikiem, zatem kumuluje się w obszarach, gdzie aktywność metaboliczna jest największa (nowotwory łagodne, złośliwe, ogniska zapalne) [28]. Stąd problemem w interpretacji obrazu PET jest odróżnienie, czy zwiększone gromadzenie wskaźnika świadczy o procesie nowotworowym, czy też nie. Co więcej na dystrybucję FDG w organizmie wpływa między innymi aktywność metaboliczna tkanek — ich zaopatrzenie w krew i szybkość glikolizy (mózg gromadzi więcej FGD), stężenie glukozy i insuliny we krwi, czy aktywność mięśni. Jak przedstawiono powyżej, stosowanie metforminy wiąże się z aktywacją AMP kinazy i pewne procesy metaboliczne ulegają wyciszeniu, a inne aktywacji. Lek ten ma również wpływ na stężenie insuliny. W oparciu o wcześniejsze dane wiadomo, że zmiany w metabolizmie glukozy oraz aktywność proliferacyjna komórek mogą wpływać na wychwyt FDG. Nie ma zbyt wielu publikacji na temat wpływu modulatorów metabolizmu glukozy, w tym metforminy, na obrazowanie przy pomocy PET-TK u pacjentów onkologicznych. W jednej z prac wykazano obecność odwracalnego zwiększenia wychwytu jelitowego FDG podczas terapii metforminą, co istotnie wpływało na interpretację obrazu. Zdaniem autorów diagnostyczne możliwości PET-TK ogranicza szczególnie intensywny rozlany wychwyt 18F-FDG w obrębie okrężnicy, w mniejszym stopniu w obrębie jelita cienkiego. Może to maskować obecność procesu nowotworowego w obrębie przewodu pokarmowego oraz rzeczywistą odpowiedź organizmu na chemioterapię [29]. W jednym z ostatnio przeprowadzonych badań, w którym ocenie poddano ludzkie i mysie komórki raka okrężnicy inkubowane z metforminą, wykazano, że lek ten inaczej wpływa na wychwyt 18F-FDG przez guz w porównaniu do innych typowych chemioterapeutyków. Najpierw pod wpływem metforminy zwiększa się komórkowy wychwyt 18F-FDG glukozy (chory może być uznany za non responder), a następnie na skutek obumierania komórek guza (efekt metforminy/ /chemioterapii) wychwyt 18F-FDG ulega zmniejszeniu. 
Taka dwufazowa odpowiedź może zakłócać ocenę skuteczności stosowanej terapii przeciwnowotworowej. Z drugiej strony należy mieć na uwadze, że nawet jeśli objętość guza ulega zmniejszeniu, to zwiększony wychwyt 18F-FGD na skutek przewlekłego pobudzenia AMP kinazy może utrudniać właściwą ocenę. Lepszym rozwiązaniem, aby oceniać skuteczność terapii u pacjentów stosujących w leczeniu modulator glukozy jakim jest metformina, wydaje się być użycie markera proliferacji 18F-FLT (18F tymidyna), a nie markera metabolizmu komórkowego, jakim jest 18F-FDG. Wychwyt tego wskaźnika dobrze koreluje z odpowiedzią guza na metforminę - zmniejszona proliferacja guza $=$ zmniejszone gromadzenia 18-FLT [30]. Wskaźnik ten nie jest powszechnie wykorzystywany. Wobec faktu, że obecnie w badaniach PET zazwyczaj stosuje się FDG, a metformina jest najczęściej przepisywanym lekiem przeciwcukrzycowym ,powinno się ją odstawić przed badaniem, aby nie zakłócała interpretacji obrazu. Nie ma jednoznacznego zdania wśród badaczy co do konkretnego okresu wash out, niemniej część autorów proponuje, aby u chorych onkologicznych odstawiać metforminę minimum 48 godzin przed badaniem [29]. Oprócz wpływu metforminy na AMP kinazę i tym samym proliferację guza wydaje się, że lek ten może wykazywać działanie antyonkogenne również poprzez wpływ na stężenie insuliny. W badaniu z wykorzystaniem mysich komórek raka okrężnicy ekspozycja na metforminę nie wpłynęła na poziom insuliny, ani wychwyt FDG przez komórki guza u myszy z normoinsulinemia natomiast stwierdzono zmniejszenie stężenia insuliny i wychwytu FDG u myszy z wyjściową hiperinsulinemią. Autorzy sugeruja, że powyższy efekt zastosowania metforminy powinien być brany pod uwagę w ocenie jej działania przeciwnowotworowego, ponieważ odpowiedź może zależeć od tego, czy ma się do czynienia z pacjentem $\mathrm{z}$ hiperinsulinemią i nowotworem wrażliwym na insulinę, czy też nie [31]. Konieczne jest dalsze poszerzanie wiedzy na temat wpływu metforminy, jako leku stosowanego w terapii cukrzycy przewlekle oraz wykorzystywanego jako terapia adjuwantowa $\mathrm{w}$ badaniach klinicznych $\mathrm{u}$ chorych onkologicznych, na wychwyt FDG i interpretację obrazu PET. Co więcej, w oparciu o przedstawione wyżej informacje nasuwa się pytanie, czy FDG jest dobrym markerem by oceniać wpływ przeciwnowotworowy metforminy [32]?

\section{Ugruntowane zastosowania kliniczne metforminy poza cukrzycą typu 2}

\section{Stan przedcukrzycowy}

Przed ujawnieniem cukrzycy często przez wiele lat mamy do czynienia z nieznacznym podwyższeniem wartości glikemii wynikającym z narastania insulinooporności i towarzyszącej jej kompensacyjnej hiperinsulinemii. Jest to tak zwany stan przedcukrzycowy. Stan przedcukrzycowy to: nieprawidłowa glikemia na czczo (IFG impared fasting glucose) (stężenie glukozy: 100-125 mg/dl) lub nieprawidłowa tolerancja glukozy (IGT — impaired glucose tolerance) stwierdzona w oparciu o wynik testu doustnego obciążenia glukozą $75 \mathrm{~g}$ (stężenie glukozy w 2 godzinie: $\geq 140 \leq 199$, według WHO, World Health Orginization); lub oba te zaburzenia jednocześnie. Zarówno nieprawidłowa glikemia na czczo, jak i nieprawidłowa tolerancja glukozy nie są stanami łagodnymi. Chorzy z tymi zaburzeniami mają wysokie ryzyko zarówno wystąpienia cukrzycy typu 2 jak i powikłań sercowo- naczyniowych. Stan przedcukrzycowy dotyczy według ostatnich danych 344 milionów osób na świecie, a liczba ta stale się zwiększa [33].

Korzyści ze stosowania metforminy $\mathrm{u}$ osób ze stanem przedcukrzycowym wykazano w 3 letnim badaniu DPP (Diabetes Prevention Program). Stosowanie metforminy zmniejszało ryzyko wystąpienia cukrzycy typu 2 o 31\%, natomiast sama zmiania stylu życia (bez leku) aż o 58\%. Redukcja masy ciała była również największa w grupie poddawanej terapii behawioralnej $-5,6 \mathrm{~kg}$, przy czym chorzy stosujący metforminę (w dawce $2 \times 850 \mathrm{mg} / 24 \mathrm{~h}$ ) zmniejszyli masę ciała o $2 \mathrm{~kg}$, w porównaniu do $0,1 \mathrm{~kg}$ redukcji w grupie placebo [34]. Blokując wątrobową produkcję glukozy, która ma miejsce głównie w godzinach nocnych, metfomina poprawia glikemię na czczo co przekłada się na zmniejszenie występowania powikłań sercowo-naczyniowych. Istnieją również dane, że u chorych z IGT stosowanie metforminy wiąże się z obniżeniem ciśnienia tętniczego krwi oraz stężenia hs-CRP [35]. Zgodnie z zaleceniami Polskiego Towarzystwa Diabetologicznego, $\mathrm{u}$ osób ze stwierdzonym stanem przedcukrzycowym (IFG lub IGT) konieczne jest zalecenie redukcji masy ciała oraz zwiększenie aktywności fizycznej. Dodatkowo należy rozważyć włączenie metforminy jako profilaktyki wystąpienia cukrzycy typu 2 u osób z grupy wysokiego ryzyka jej rozwoju, szczególnie obciążonych kardiologicznie, które nie potrafią (nie chcą) zmodyfikować swojego stylu życia.

\section{Insulinooporność i zespót metaboliczny}

Insulinooporność oznacza brak właściwej odpowiedzi organizmu na insulinę. Insulinooporność na wiele lat może wyprzedzać rozwój cukrzycy typu 2. Jest to stan, w którym zarówno endogenna, jak i egzogenna insulina nie wywierają właściwego wpływu na wychwyt i utylizację glukozy jaki ma miejsce u osób zdrowych. Powstaniu insulinooporności sprzyjają między innymi zaburzenia ekspresji białek uczestniczących w szlaku działania insuliny oraz otyłość trzewna. Adipocyty trzewnej tkanki tłuszczowej są duże i mają większą aktywność metaboliczną, 
są też mniej wrażliwe na insulinę [36]. Najważniejszą cechą insulinooporności tkanki tłuszczowej jest zmniejszone hamowanie lipolizy przez insulinę, co skutkuje zwiększonym stężeniem wolnych kwasów tłuszczowych. Nadmiar wolnych kwasów tłuszczowych zmniejsza wychwyt mięśniowy glukozy; prowadzi również do zaburzeń w sygnalizacji insuliny. Do osłabienia wrażliwości na insulinę dochodzi również w sposób naturalny wraz z wiekiem, prawdopodobnie na skutek zwiększania się ilości trzewnej tkanki tłuszczowej oraz stężenia czynników zapalnych i odkładania się triacylogliceroli w komórkach [4]. Obecność insulinooporności może prowadzić do rozwoju stanu przedcukrzycowego, cukrzycy typu 2, zespołu metabolicznego i PCOS. Insulinooporność/ /jawna cukrzyca typu 2 jest jedną ze składowych zespołu metabolicznego [37]. W oparciu o dane na temat plejotropowego działania metforminy stosowanie jej w powyższych stanach jest jak najbardziej uzasadnione [38]. Metformina zmniejszając insulinooporność i tym samym kompensacyjną hiperinsulinemię jest szansą na odroczenie cukrzycy typu 2.

Insulinooporność może występować również wtórnie w przebiegu schorzeń, takich jak: marskość wątroby, choroby nowotworowe, choroby z autoagresji, mocznica, endokrynopatie: zespół Cushinga, akromegalia czy pheochromocytoma [4].

Okazuje się, że nie tylko nadmiar, ale i niedobór tkanki tłuszczowej prowadzi do insulinooporności, co widoczne jest między innymi w zespołach lipodystrofii (lipoatrofii). W zaburzeniach tych stosuje się również metforminę $[39,40]$.

\section{Zespót policystycznych jajników}

W PCOS zwykle występuje wtórna do insulinooporności kompensacyjna hiperinsulinemia, co wydaje się mieć istotne znaczenie $\mathrm{w}$ powstawaniu hiperandrogenizmu, ponieważ prowadzi do pobudzenia komórek pęcherzyków, na których znajdują się receptory dla IGF- 1 i insuliny. Insulina może modyfikować receptory dla LH na komórkach tekalnych pęcherzyków, przyczyniając się w ten sposób do zwiększonej androgenezy. Równoczasowo występują zatem oporność tkanek obwodowych na insulinę i zwiększona wrażliwość jajnika na insulinę. Poza tym hiperinsulinemia zmniejsza stężenie białka nośnikowego dla IGF-1 (IGFBP-1, ang. IGF binding protein), co skutkuje zwiększonym stężeniem dostępnego IGF-1 który, wzmaga stymulację jajnika przez LH do produkcji androgenów [41]. Zwiększone stężenie insuliny wiąże się również ze zmniejszeniem stężenia SHGB (ang. sex hormone binding globulin), co skutkuje nadmiarem czynnego testosteronu. Wykazano, że insulinooporność dotyczy nie tylko otyłych ale i szczupłych kobiet z PCOS [42, 43]. Pacjentki z zespołem policystycznych jajników mają zwiększone ryzyko wystąpienia zespołu metabolicznego i jego konsekwencji pod postacią powikłań sercowo-naczyniowych oraz stanu przedcukrzycowego i cukrzycy typu 2. Od wielu lat metformina ma swoje miejsce w leczeniu zespołu policystycznych jajników. Lek ten zmniejszając insulinooporność u chorych z PCOS, wpływa korzystnie na płodność, reguluje cykle miesięczne, zmniejsza hirsutyzm oraz może prowadzić do redukcji masy ciała [43]. Wykazano, że metformina znamiennie obniża stężenie proinsuliny i androstendionu, szczególnie u pacjentek z PCOS z towarzyszącą nadwagą lub otyłością [44]. Ponadto lek ten wpływa na poprawę parametrów gospodarki lipidowej i obniżenie stężenia CRP. Leczenie skojarzone cytrynianem klomifenu i metforminą poprawia częstość owulacji, a tym samym zwiększa liczbę ciąż. Lek ten stosowany jest zatem zarówno w leczeniu objawów PCOS, jak i w leczeniu niepłodności [45]. U pacjentek z PCOS stosujących metforminę przed i w trakcie ciąży stwierdzono zmniejszoną częstość poronień samoistnych, powikłań położniczych i wad rozwojowych płodu oraz mniejsze ryzyko rozwoju cukrzycy ciążowej (GDM) [46, 47]. Należy podkreślić, że stosowanie metforminy nie zwalnia chorych z PCOS z konieczności modyfikacji stylu życia (właściwa dieta oraz aktywność fizyczna).

\section{Podsumowanie}

Metformina jest najczęściej przepisywanym doustnym lekiem przeciwcukrzycowym na świecie. Jej pozycja w leczeniu cukrzycy typu 2 jest ugruntowana od ponad dwóch dekad. Lek ten od wielu lat stosowany jest również w leczeniu stanu przedcukrzycowego, zespołu policystycznych jajników i stanów insulinooporności. Dodatkowe, korzystne działanie leku na układ sercowo-naczyniowy oraz coraz częściej postulowany efekt przeciwnowotworowy, tym bardziej uzasadniają obecność metforminy na każdym szczeblu algorytmu leczenia cukrzycy typu $2 \mathrm{w}$ krajowych i światowych rekomendacjach towarzystw diabetologicznych. Namacalnym efektem ingerencji leku w metabolizm glukozy i nowotworów są obrazy uzyskane przy pomocy PET z wykorzystaniem FDG jako radioznacznika. Należy jednak mieć na uwadze fakt, że przyjmowanie metforminy przewlekle przez chorych na cukrzycę typu 2, jak i przez chorych onkologicznych w formie terapii adjuwanowej wpływa istotnie na interpretację uzyskanego obrazu, stąd najlepiej lek odpowiednio wcześnie odstawić. Obecnie trwają liczne badania, które z pewnością poszerzą naszą wiedzę na temat mechanizmów działania metforminy oraz dadzą ostateczną odpowiedź, czy lek ma rzeczywiście działanie przeciwnowotworowe u ludzi, i czy wydłużenie życia nicieni i gryzoni poddawanych terapii może przełożyć się również na ssaki naczelne. 